University of Nebraska - Lincoln

DigitalCommons@University of Nebraska - Lincoln

1985

\title{
CRYOGENIC PRESERVATION OF SEMEN FROM THE GREATER SANDHILL CRANE
}

George F. Gee

Patuxent Wildlife Research Center

Murray R. Bakst

Agricultural Research Service

Thomas J. Sexton

Agricultural Research Service

Follow this and additional works at: https://digitalcommons.unl.edu/usdaarsfacpub

Part of the Agricultural Science Commons

Gee, George F.; Bakst, Murray R.; and Sexton, Thomas J., "CRYOGENIC PRESERVATION OF SEMEN FROM THE GREATER SANDHILL CRANE" (1985). Publications from USDA-ARS / UNL Faculty. 636.

https://digitalcommons.unl.edu/usdaarsfacpub/636

This Article is brought to you for free and open access by the U.S. Department of Agriculture: Agricultural Research Service, Lincoln, Nebraska at DigitalCommons@University of Nebraska - Lincoln. It has been accepted for inclusion in Publications from USDA-ARS / UNL Faculty by an authorized administrator of DigitalCommons@University of Nebraska - Lincoln. 


\section{CRYOGENIC PRESERVATION OF SEMEN FROM THE GREATER SANDHILL CRANE}

GEORGE F. GEE, Patuxent Wildlife Research Center, Laurel, MD 20708

MURRAY R. BAKST, Agricultural Research Service, Avian Physiology Laboratory, Beltsville, MD 20705

THOMAS J. SEXTON, Agricultural Research Service, Avian Physiology Laboratory, Beltsville, MD 20705

J. WILDL. MANAGE. 49(2):480-484

Frozen gene pools (semen or embryos) can provide a safe place for the storage of genetic material for many generations. Cranes (Grus spp.) are one of many species in need of gene pool protection. Of the seven species and four subspecies considered rare or endangered (Archibald et al. 1981), two, the whooping crane (G. americana) and the Mississippi sandhill crane (G. canadensis pulla), are part of captive propagation projects at the Patuxent Wildlife Research Center in Laurel, Maryland. Greater sandhill crane (G. c. tabida) semen cryopreservation, under study at Patuxent since 1976 (Sexton and Gee 1978; Gee and Sexton 1979, 1980 ), indicated a need to reevaluate semen diluents and cryoprotectant levels.

The present paper summarizes experiments that were designed to determine the effects of semen diluents and cryoprotectant levels on viability of frozen-thawed crane semen, sperm damage before freezing and after thawing, and techniques that would result in increased numbers of fertile eggs and progeny from cranes inseminated with frozen-thawed semen.

\section{METHODS}

Artificial insemination techniques, semen evaluation methods, and crane management regimes used in this study were described by Gee and Temple (1978) and Gee and Sexton (1979, 1980). The present study consisted of 12 experiments: 9 experiments to determine optimum conditions for semen collection, semen dilution, freezing, and thawing, and 3 insemination trials with frozen semen. The $t$ test was used to test the significance of differences between two sample means (Steel and Torrie 1960). The oneway classification analysis of variance and Duncan's Multiple Range Test were used where appropriate (Steel and Torrie 1960).

\section{Sample Preparation}

Experiment 1 was designed to study the effect of semen temperature before cryopreservation on sperm survival in the frozen-thawed sample. Clean, individual semen samples were collected, diluted, and transferred to $1-\mathrm{ml}$ collection vials. The vials were held at either 3,6 , 9 , or $12 \mathrm{C}$ before adding the cryoprotectant and freezing. In all 12 experiments, sperm survival was determined from three $5 \%$ eosin- $10 \%$ nigrosin stained slides. In Experiment 2, fresh semen was diluted at the time of collection or at the time the cryoprotectant was added. DMSO (4\%) was added to both samples, the samples frozen, and sperm survival in the frozen-thawed samples compared.

Because the $\mathrm{pH}$ (7.4) and osmolality (330 mosM) of the Beltsville Poultry Semen Extender (BPSE, Sexton 1977) did not reflect that of crane semen (greater sandhill $[7.5 \pm 0.5 \mathrm{pH}$, $296 \pm 32$ mosM], Florida sandhill [G. c. pratensis $][8.0 \pm 0.1 \mathrm{pH}, 302 \pm 12 \operatorname{mosM}]$, Mississippi sandhill $[8.0 \pm 0.1 \mathrm{pH}, 311 \pm 17 \operatorname{mos} \mathrm{M}]$, whooping crane $[8.0 \pm 0 \mathrm{pH}, 270 \pm 36 \operatorname{mosM}])$, a new crane extender was developed. Osmolality (8- $\mu$ l semen sample) was determined using a Wescor 5100 B Vapor Pressure Osmometer (Wescor, Inc., Logan, Utah) and $\mathrm{pH}$ from a drop of semen on Duren paper (Macherey-Nagel and Co., Duren, Germany) in the appropriate range. The crane extender was prepared 
by adjusting the $\mathrm{pH}$ and osmolality of BPSE to $7.8 \mathrm{pH}$ with sodium hydroxide and to $310 \operatorname{mos} \mathrm{M}$ with distilled water.

\section{Cryoprotectant}

Experiment 3 was conducted to examine the effect of holding semen up to 3 hours (extender equilibration) before adding DMSO. Diluted semen samples were held at $3,6,9$, or $12 \mathrm{C}$ before adding DMSO and freezing. Sperm survival in the frozen-thawed sample for each equilibration time of $0.5,1.0,1.5,2.0,2.5$, and 3.0 hours was compared. Experiment 4 was conducted to compare the addition of concentrated DMSO to semen, with the addition of DMSO diluted with BPSE. DMSO or DMSO diluted with BPSE was added to obtain a $4 \%$ concentration at a 1:2 dilution rate. Experiment 5 was conducted to compare the cryoprotectant effect of DMSO concentration in crane extender on sperm survival in the frozen-thawed sample. Diluted DMSO was added to pooled semen to obtain DMSO concentrations from 2 to $6 \%$. In addition, separate studies were conducted comparing $3 \%$ with $4 \%$ DMSO, or $5 \%$ with $6 \%$ DMSO in crane extender.

\section{Frozen-Thawed Semen}

After thawing in an ice bath, semen was removed from the straw with a 1-ml syringe, and sperm survival was determined. A comparison was made of samples thawed, as described previously, with those thawed and immediately diluted with an equal quantity of chilled (1 C) BPSE (Experiment 6). Frozen semen straws were thawed 4-10 weeks (short-term storage) and 8-10 months (long-term storage) after freezing. The effects of short-term (Experiment 7) and long-term storage (Experiment 8) on sperm survival were compared.

\section{Fine Structure}

Semen samples (undiluted, diluted with crane extender, diluted plus 6\% DMSO, or diluted plus $6 \%$ DMSO frozen and thawed) were prepared for scanning electron microscopy (SEM), Experiment 9 . The samples were examined for progressive motility and percentage live spermatozoa before fixation for SEM. Semen samples were placed in $2 \%$ glutaraldehyde in 0.15 $M$ cacodylate buffer, $\mathrm{pH}$ 7.4. Samples were stored at 5-6 C for 2-3 weeks before dehydration in an ascending series of ethanols. Criticalpoint dried spermatozoa were deposited on double-sticky Scotch tape attached to aluminum stubs and examined with either a Hitachi 430 or a Hitachi HHS-2R (Hitachi, Ltd., Tokyo, Japan) Scanning Electron Microscope.

\section{Insemination Trials}

Four pairs of greater sandhill cranes were used for insemination with frozen-thawed semen. Crane pairs were housed outside in 186$\mathrm{m}^{2}$ pens, separated from the females by a $2.4-$ $\mathrm{m}$-high wire fence beginning in February, 2 months before egg production and throughout the reproductive season (Apr-Jun). Eggs were collected and artificially incubated in a Petersime Model 4 forced-draft incubator (Petersime Incubator Co., Gettysburg, Ohio) at $37.7 \mathrm{C}$ and $55 \%$ relative humidity. After 30 days, unhatched eggs were examined for fertility.

Inseminations began before the first egg was laid and were made on Monday, Wednesday, and Friday and on the day of oviposition. Frozen-thawed semen was inseminated in the vagina or in the urodeum adjacent to the vagina. The volume of frozen-thawed semen per insemination was $0.25 \mathrm{ml}$ in Trials 1 and 2 and $0.50 \mathrm{ml}$ in Trial 3. In addition, fresh semen was diluted 1:2 in Trials 1 and 3, and 1:1 in Trial 2 (Table 1).

\section{RESULTS AND DISCUSSION}

Several pre-freeze manipulations increased survival of spermatozoa in frozen-thawed semen. In Experiment 4, with BPSE and 4\% DMSO, a larger percentage of spermatozoa survived the freezing-thawing procedure in four of five replicates $(P \leq 0.1)$ when DMSO was diluted with BPSE before adding to the semen $(61 \pm 10 \%)$ rather than adding the DMSO directly to the semen pool $(46 \pm 12 \%)$.

The $6 \%$ DMSO level provided the greatest percentage of live, motile spermatozoa (55\%) from the frozen-thawed semen when compared to $2(16 \%), 3(25 \%), 4(36 \%)$, and $5 \%$ $(36 \%)$. The percent live cells recovered from the frozen-thawed semen in Trial $3(49 \pm 5 \%)$ in $6 \%$ DMSO in crane extender was greater than in Trials $1(40 \pm 4 \%)$ and $2(35 \pm 5 \%)$ and greater than reported previously with $4 \%$ DMSO (Gee and Sexton 1979).

Several pre-freeze and post-thaw manipulations had little influence on sperm survival. These were: semen holding temperatures of 3$12 \mathrm{C}$ (Experiment 1); semen holding time of 30-75 minutes before DMSO addition (Exper- 
Table 1. Frozen-thawed semen used in Trials 1, 2, and 3; protocol for semen collection and cryopreservation.

\begin{tabular}{|c|c|}
\hline Pen temperature & Ambient, from -12 to $27 \mathrm{C}$ \\
\hline $\begin{array}{l}\text { Semen holding } \\
\text { temperature }\end{array}$ & 3 to $12 \mathrm{C}$ \\
\hline Holding time & $\begin{array}{l}\text { Variable from } \leq 0.5 \text { hour to } \leq 3 \\
\text { hours }\end{array}$ \\
\hline $\begin{array}{l}\text { Equilibration } \\
\text { time }\end{array}$ & $15 \mathrm{~min}$ \\
\hline $\begin{array}{l}\text { Laboratory } \\
\text { temperature }\end{array}$ & $22 \mathrm{C}$ \\
\hline Freeze rate & $\begin{array}{l}\geq 5 \mathrm{C} \text { to }-20 \mathrm{C},-1 \mathrm{C} / \mathrm{min} \\
-20 \mathrm{C} \text { to }-80 \mathrm{C},-50 \mathrm{C} / \mathrm{min} \\
-80 \mathrm{C} \text { to }-196 \mathrm{C},-160 \mathrm{C} / \\
\quad \min \end{array}$ \\
\hline Thaw rate & $3 \mathrm{~min}$ in a $0.5 \mathrm{C}$ ice bath \\
\hline \multicolumn{2}{|l|}{ Extender } \\
\hline $\begin{array}{l}\text { Trials } 1 \text { and } 2 \\
\text { Trials } 2 \text { and } 3\end{array}$ & $\begin{array}{l}\text { BPSE }^{a}, \text { pH } 7.4 \text { and } 330 \text { mosM } \\
\text { Crane }^{b}, \mathrm{pH} 7.8 \text { and } 310 \text { mosM }\end{array}$ \\
\hline \multicolumn{2}{|c|}{ Dilution when collected } \\
\hline $\begin{array}{l}\text { Trial } 1 \\
\text { Trial } 2 \\
\text { Trial } 3\end{array}$ & $\begin{array}{l}1: 1 \\
1: 0.5 \\
1: 1\end{array}$ \\
\hline \multicolumn{2}{|l|}{ Final dilution rate } \\
\hline $\begin{array}{l}\text { Trial } 1 \\
\text { Trial } 2 \\
\text { Trial } 3\end{array}$ & $\begin{array}{l}1: 2 \\
1: 1 \\
1: 2\end{array}$ \\
\hline \multicolumn{2}{|c|}{ Final concentration $\mathrm{DMSO}^{c}$} \\
\hline $\begin{array}{l}\text { Trial } 1 \\
\text { Trial } 2 \\
\text { Trial } 3\end{array}$ & $\begin{array}{l}4 \% \\
3+4 \% \\
6 \%\end{array}$ \\
\hline \multicolumn{2}{|c|}{ Semen inseminated } \\
\hline $\begin{array}{l}\text { Trial } 1 \\
\text { Trial } 2 \\
\text { Trial } 3\end{array}$ & $\begin{array}{l}0.25 \mathrm{ml} \\
0.25 \mathrm{ml} \\
0.50 \mathrm{ml}\end{array}$ \\
\hline
\end{tabular}

a Composition of BPSE described by Sexton (1977).

b BPSE adjusted to the $\mathrm{pH}$ and osmolality of crane semen $(7.8 \mathrm{pH}$ and 310 mosM)

c DMSO diluted with semen extender before final semen dilution.

iment 3); semen dilution when collected or 3090 minutes later (Experiment 2); and dilution after thawing (Experiment 6).

Sperm survival in straws from the same semen pool was not affected by storage or thawing. Semen straws were filled with $0.3-\mathrm{ml}$ aliquots from each semen pool and frozen at one time but on different aluminum canes. In Experiment 7 , survival of semen stored for 4-10 weeks but thawed on different days in the same 30-day period was similar. The first samples thawed averaged $50 \pm 13 \%$ live, and the second samples thawed averaged $47 \pm 12 \%$ live spermatozoa. In Experiment 8, sperm survival in semen stored for $<1.5$ months and those stored for $>8$ months was similar. The samples thawed after 1.5 months averaged $40 \pm 9 \%$ and those thawed after 8 months averaged $44 \pm 13 \%$ live spermatozoa.

Based on SEM, the addition of crane diluent and the subsequent addition of 6\% DMSO did not appear to be detrimental to spermatozoa. Normal appearing spermatozoa in undiluted, diluted, and diluted plus 6\% DMSO semen were simple, filiform-shaped cells which tapered from about $0.8 \mu \mathrm{m}$ maximum head diameter to about $0.25 \mu \mathrm{m}$ diameter at the tail just distal to the mitochondrial sheath. Although no attempt at quantification was made, it was obvious that most spermatozoa in undiluted, diluted, and diluted plus DMSO semen exhibited some structural abnormality (Fig. la, b). Head abnormalities were most prevalent and ranged from local dilations (possibly due to unequal condensation of chromatin material) to an overall thickening and irregularity of the sperm head. More extreme abnormalities included spherical or oblong shaped heads from which a tail projected. Occasionally the sperm plasmalemma had a ruffled appearance or was partially disrupted, exposing the mitochondrial sheath or conical shaped acrosome. Whether such structural diversity can be correlated with the low percentage of live sperm scores seen in the present study is not known. Nevertheless, such structural variation has been noted previously (Gee and Temple 1978, Sharlin et al. 1979, Russman and Harrison 1982).

Most frozen-thawed crane spermatozoa were extensively damaged, particularly at the midpiece where the mitochondrial sheath was exposed, revealing rounded and dislodged mitochondria (Fig. 1c, d). Such freeze-thaw damage is qualitatively similar to that observed by Harris et al. (1973) and Bakst and Sexton (1979) in the chicken and by Marquez and Ogasawara (1977) and Bakst and Sexton (1979) in the turkey (Meleagris gallopavo). These authors attributed the damage to osmotic stress.

\section{Insemination Trials}

In the insemination study (Trials 1 and 2), changes made in the technique reported earlier (Gee and Sexton 1979) resulted in decreased fertility and sperm survival in the frozenthawed semen. However, further modifications (Trial 3) resulted in the largest number of fertile eggs (16) and chicks (8) ever obtained from cranes inseminated with frozen-thawed semen (Table 2). Technique refinements, such as the 

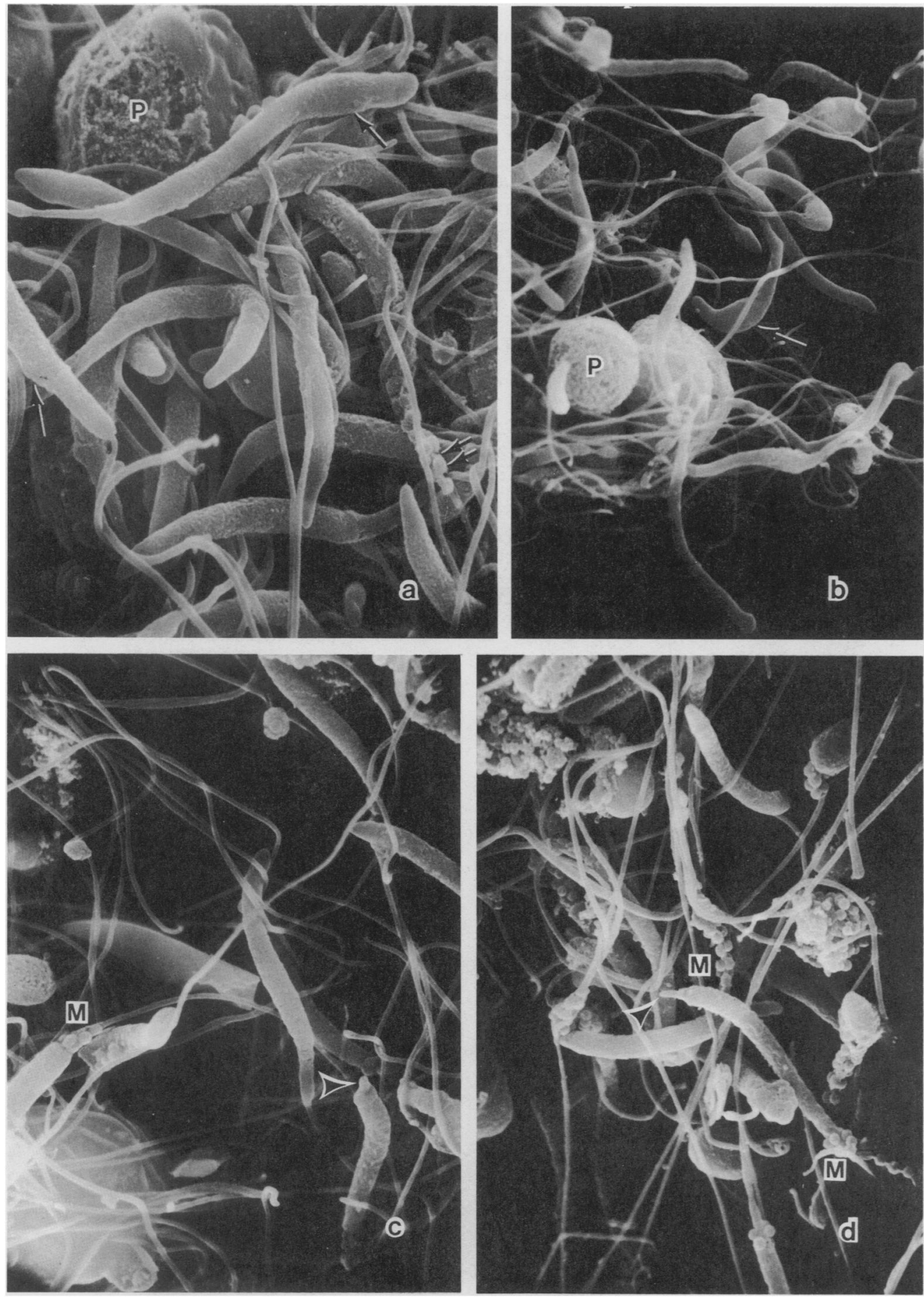

Fig. 1. Scanning electron micrographs of greater sandhill crane spermatozoa: (a) fresh semen $(\times 8,000)$; (b) fresh semen in crane semen extender ( $\times 4,000)$; (c) and (d) frozen-thawed semen in crane semen extender and 6\% DMSO $(\times 6,000)$. Morphologically normal and abnormal spermatozoa are observed before freezing (a, b): Abnormal forms include swollen head (arrows) and plasma membrane loss (double arrows). Porous structures $(P)$ of unknown origins are routinely found in the semen sample. After freezing, most spermatozoa are characterized by plasma membrane loss and swollen or displaced mitochondria (M) (c, d). Loss of the acrosome (arrowhead) was also observed. A normal spermatozoan is observed in (c). 
Table 2. Fertile eggs from cranes inseminated with frozenthawed semen (Trials 1-3).

\begin{tabular}{|c|c|c|c|c|c|c|}
\hline \multirow[b]{2}{*}{ Trial no. } & \multirow{2}{*}{$\begin{array}{l}\text { Live sperm per } \\
\text { insemination } \\
\left(10^{6}\right)\end{array}$} & \multirow{2}{*}{$\begin{array}{l}\text { Eggs } \\
\text { laid }\end{array}$} & \multicolumn{2}{|c|}{ Fertility } & \multicolumn{2}{|c|}{$\begin{array}{l}\text { Hatchabilitya } \\
\text { of fertile } \\
\text { eggs }\end{array}$} \\
\hline & & & $N$ & $\%$ & $N$ & $\%$ \\
\hline 1 & $6.4 \pm 0.5$ & 30 & 4 & 13 & 1 & 25 \\
\hline 2 & $8.6 \pm 2.4^{b}$ & 21 & 1 & 5 & 0 & 0 \\
\hline 3 & $16.0 \pm 3.5$ & 32 & $16^{c}$ & 50 & 8 & 50 \\
\hline Total & & 83 & 21 & 25 & 9 & 43 \\
\hline
\end{tabular}

a Eggs artificially incubated.

b Dilution rate was $1: 2$ in Trials 1 and 3 , and $1: 1$ in Trial 2

c Significantly greater $P \leq 0.025$ (Trial 3 vs. Trials 1 and 2).

new crane extender, increasing the level of DMSO to $6 \%$, and increasing the number of live spermatozoa per insemination, contributed to the improved fertility in Trial $3(P \leq 0.025)$.

Gee and Sexton (1979) indicated that the number of spermatozoa inseminated $(20$ million/insemination) was an important factor in subsequent crane fertility. According to our estimates (Table 2), 16 million live spermatozoa per insemination were used in Trial 3 and fewer than that in the other two trials. Although the number of live spermatozoa per insemination in Trial 2 was greater than in Trial 1, the number of live spermatozoa inseminated was smaller than the number inseminated in Trial 3.

The technique developed provides a viable method for the preservation of crane semen. Using the crane extender plus 6\% DMSO, $50 \%$ of sperm survived the freezing-thawing process, and $50 \%$ of eggs laid by cranes inseminated with frozen-thawed semen were fertile. Also, an increase in the number of live spermatozoa per insemination to 25 or 30 million should improve fertility. This technique makes it possible to store semen and to use semen when needed to restore genetic diversity.

\section{LITERATURE CITED}

Archibald, G. W., Y. Shigeta, K. Matsumoto, and K. Momose. 1981. Endangered cranes. Pages 1-12 in J. C. Lewis and H. Masatomi, eds. Crane research around the world. Int. Crane Found., Baraboo, Wis.

BAKST, M. R., AND T. J. Sexton. 1979. Fertilizing capacity and ultrastructure of fowl and turkey spermatozoa before and after freezing. J. Reprod. Fertil. 55:1-7.

GeE, G. F., AND T. J. Sexton. 1979. Artificial insemination of cranes with frozen semen. Proc. Int. Crane Workshop 2:89-94.

$\longrightarrow$, AND $\longrightarrow$ 1980. Artificial insemination and semen preservation of nondomestic birds. Annu. Proc. Am. Assoc. Zoo Vet. 55-58.

$\longrightarrow$, AND S. A. TEMPle. 1978. Artificial insemination for breeding non-domestic birds. Symp. Zool. Soc. London 43:51-72.

Harris, G. C., JR., R. J. Thurston, and J. Cundall. 1973. Changes in the ultrastructure of the fowl spermatozoon due to rapid freeze-thaw. J. Reprod. Fertil. 34:389-394.

Marquez, B. J., and F. X. Ogasawara. 1977. Ultrastructural changes in turkey spermatozoa after immersion in glycerolyzed media and during various steps used in cryopreservation. Poult. Sci. 56:1806-1813.

Russman, S. E., AND P. C. Harrison. 1982. Sperm morphology in the crane. Proc. Int. Crane Workshop 3:199-212.

SEXTON, T. J. 1977. A new poultry semen extender I. Effect of extension on the fertility of chicken semen. Poult. Sci. 56:1443-1446.

$\longrightarrow$, AND G. F. GEE. 1978. A comparative study on the cryogenic preservation of semen from the sandhill crane and the domestic fowl. Symp. Zool. Soc. London 43:89-95.

Sharlin, J. S., C. S. Shaffner, AND G. F. Gee. 1979. Sperm head length as a predictor of fecundity in the sandhill crane, Grus canadensis. J. Reprod. Fertil. 55:411-413.

Steel, R. G. D., AND J. H. Torrie. 1960. Principles and procedures of statistics. McGraw-Hill Book Co., New York, N.Y. 481pp.

Received 13 February 1984. Accepted 10 July 1984. 